\title{
HUBUNGAN PEMIKIRAN PENDIDIKAN AL MAWARDI RELEVANSINYA DENGAN NILAI-NILAI PENDIDIKAN ISLAM ANTARA BATASAN GURU DENGAN MURID
}

\author{
Ridwan \\ Universitas Muhammadiyah Malang \\ Jln. Bendungan Sutami No.188, Sumbersari, Lowokwaru, \\ Sumbersari, Kec. Lowokwaru, Kota Malang, Jawa Timur 65145 \\ Email: Gayokuridwan93@gmail.com \\ DOI: $10.29313 /$ tjpi.v6i2.3157
}

Accepted: October 24th, 2017. Approved: January 18th, 2018. Published: January 18th, 2018

\begin{abstract}
ABSTACT
Al-Mawardi demanded that a teacher be sincere in performing his duties. Educating should be oriented towards higher goals, to teach and educate, is a scientific activity that has value and high position, which is not in tune with the material. Imam Al-Mawardi forbade anyone to teach and educate on the basis of economic motives. A teacher will perform his duties professionally, marked by some attitudes. First; always prepare everything needed to support the learning process, second; a teacher who will act exactly the sincere promise and completion of his duty; third; the use of free time will be directed to his professional interests, fourth; persistence and perseverance in working. A sincere Master will realize the importance of perseverance and perseverance to accomplish this task, the fifth; High creativity and innovation arise from awareness of the rising demands and challenges of educational prospects. Then in the process of learning certainly cannot be separated by the values of Islam that must be inculcated in the teacher as well as must have the attitude, humble, exemplary, piety of the god who is ESA.
\end{abstract}

Keywords: Al Mawardi Thought, Values Islam, Teacher and Student.

\section{ABSTRAK}

Al-Mawardi menuntut agar seorang guru tulus dalam menjalankan tugasnya. Mendidik harus berorientasi pada tujuan yang lebih tinggi, untuk mengajar dan mendidik, adalah aktivitas ilmiah yang memiliki nilai dan posisi tinggi, yang tidak selaras dengan materi. Imam Al-Mawardi melarang seseorang untuk mengajar dan mendidik. berdasarkan motif ekonomi. Seorang guru akan melakukan tugasnya diengan profesional, dengan ditandai oleh beberapa sikap. Pertama; selalu siapkan segalanya yang dibutubkan untuk mendukung proses belajar mengajar, kedua; seorang guru yang akan bertindak persis janji yang tulus dan selesainya tugasnya, ketiga; penggunaan waktu luang akan diarabkan untuk kepentingan profesionalnya, keempat; ketekunan dan kegigihan dalam bekerja. Guru yang tulus akean menyadari pentingnya ketekunan dan kegigiban untuk mencapainya tugasnya, yang kelima; Kreativitas dan inovasi yang tinggi, timbul dari kesadaran akan adanya meningkatnya tuntutan dan tantangan prospek pendidikan. Kemudian dalam prosses pembelajaran tentu tidak bisa dipisabkan dengan nilai-nilai Islam yang harus ditanamkan dalam diri guru seperti halnya harus memiliki sikap, rendah hati, keteladanan, ketakwaan terhadap tuhan yang maha Esa.

Kata Kunci: Pemikiran Al Mawardi, Nilia-Nilai Islam, Guru dan Murid. 


\section{PENDAHULUAN}

Pendidikan merupakan bagian yang terpenting dalam kehidupan manusia yang sekaligus membedakan manusia dengan hewan, manusia di karunia Tuhan akal dan pikiran, sehingga manusia mengetahui segala hakekat permasalahan dan sekaligus dapat membedakan antara yang baik dan yang buruk dalam dirinya maupun kehidupan masyarakat dan bangsa (Tatang M. Amrin, 2011: 7). Jika berbicara pendidikan, dalam konteks pendidikan yang dialami oleh bangsa Indonesia dewasa ini tidak akan pernah ada habisnya. Pendidikan adalah permasalahan yang tidak pernah putus karena menyangkut persoalan manusia dalam rangka memberi makna dan moral. Ada banyak hal yang harus dibenahi menyangkut persoalan yang datang dari luar dunia pendidikan, mulai dari masalah birokrasi pendidikan yang masih tumpang tindih, simpang siur dan tidak terkoordinasi dengan baik sampai dengan masalah internal pendidikan itu sendiri, yakni mengenai konsep pendidikan dan aplikasi praksis menciptakan pendidikan yang tepat dan akurat bagi kondisi bangsa.

Bangsa Indonesia sebagai bangsa yang mayoritas penduduknya adalah pemeluk agama Islam, dalam rangka pelestarian dan pengembangan kebudayaan yang mengedepankan dan menjunjung tinggi nilai moralitas melalui cipta karya manusia, dengan pengoptimalan potensinya, mempunyai andil yang sangat besar untuk mewujudkannya. Umat Islam mempunyai tanggung jawab yang besar akan hal itu. Namun ditengah pusaran berbagai ideologi, pandangan, teori pendidikan yang berbasis kultur peradaban barat, seperti liberalisme, esensialisme, progresifisme, nativisme, empirisme dan konfergensi wacana pendidikan Islam nampaknya selalu marginal. Ide-ide dan teori pendidikan yang lahir dari konsepsi Islam sangat sulit dijual keruang publik. Orang berfikir bahwa pendidikan Islam lebih berurusan dengan wilayah terbatas dari sebuah aktifitas manusia terkait dengan perbaikan moral (Aziza Aryanti, 2016).

Kemudian dewasa ini, telah muncul gejala yang kurang baik yang menimbulkan kegoncangan dalam kehidupan keluarga, masyarakat dan bangsa, diantaranya adalah kenakalan remaja, tauran, korupsi oleh para pejabat negara. Salah satu faktor penyebab timbulnya kenakalan remaja, karena kurangnya perhatian orang tua terhadap anak, utamanya pembinaan akhlak. Pembinaan akhlak adalah mutiara hidup yang membedakan makhluk manusia dan makhluk hewani. Manusia tanpa akhlak akan hilang derajat kemanusiaannya sebagai mahkluk mulia, sesuai dengan fitrah, dan yang memiliki peran sebagai hamba dan khalifah Allah di muka bumi. Oleh karena itu, nilai-nilai akhlak harus ditanamkan sejak dini baik melalui pendidikan keluarga, masyarakat, maupun lembaga pendidikan formal yaitu sekolah. Suatu bangsa akan jaya dan terkenal bukan ditentukan oleh keluasan wilayah, kekayaan sumber daya alam, serta kuantitas penduduknya, akan tetapi adalah karena kualitas akhlak atau tingginya nilai nilai peradaban yang dimilikinya oleh peserta didik di Indonesia.

Jika dilihat dengan kaca mata kita bahwa pendidikan, hal yang demikian itu mungkin terjadi, karena memang selama ini pendidikan kita lebih berkonsentrasi kepada pembangunan ekonomi pragmatis dengan orientasi keuntungan jangka pendek yang lebih kasat mata, imbasnya pada pendidikan ialah terbengkalainya pendidikan Nasional kita, pantaslah apa yang dikatakan Ahmad Tafsir bahwa "pendidikan kita dianggap gagal karena tidak mampu menghasilkan manusia berkualitas, beriman, dan berakhlak mulia di masyarakat.

Kemudian jika kita telaah lebih dalam nilai nilai Islam itu harus di miliki oleh setiap pendidik, seperti halnya etika, moral, tawadhu, rendah hati, beserta akhlakul karimah, dimana seorang pendidik harus memiliki sikap profesional, sikap sosial, dan pengetahuan yang banyak sehingga dalam proses pembelajaran yang 
berlangsung di setiap lembaga agar membawa hasil yang lebih baik dan memiliki ouput bisa di terimana di masyarakat banyak.

\section{PEMBAHASAN}

\section{Riwayat hidup Al-Mawardi}

Ulama penganut Mazhab Syafi'i ini bernama lengkap Abu al-Hasan Ali bin Habib al-Mawardi al-Bashry, panggilannya Abul Hasan, gelarnya al-Mawardi, diambil dari gelar keluarganya yang menjual maaul ward (air mawar) (Al-Mawardi, 1994: 3). Lahir di kota pusat peradaban Islam klasik, Basrah (Irak) pada tahun $364 \mathrm{H}$. al-Mawardi menerima pendidikan pertamanya di kota kelahirannya, ia belajar ilmu hukum dari Abul Qasim Abdul Wahid as-Saimari (AlMawardi, 1994: 4).

Di kota ini juga al-Mawardi sempat mempelajari hadis dari beberapa ulama terkenal seperti al-Hasan bin Ali bin Muhammad bin al-Jaily, Abu Khalifah alJumhy, Muhammad bin 'Adiy bin Zuhar alMarzy, Muhammad bin al-Ma'aly al-Azdy serta Ja'far bin Muhammad bin al-Fadl alBaghdadi (Al-Mawardi, 1988: 58). Menurut pengakuan muridnya, Ahmad Bin Ali alKhatib (Musthofa, 1995: 21) bahwa dalam bidang Hadis, Al-Mawardi termasuk orang yang tsiqoh. Selain mendalami bidang Hadis, al-Mawardi juga mendalami bidang fikih pada syekh Abu al-Hamid alIsfarayyini (Ibnu Katsir, 3). Sehingga ia tampil sebagai salah seorang ahli fikih terkemuka dari Madzhab Syafi'i. Keahlian al-Mawardi selanjutnya juga dalam bidang sastra dan sya'ir, nahwu, filsafat dan ilmu sosial, namun belum dapat diketahui secara pasti dari mana ia mempelajari ilmu kebahasaan tersebut. Dalam waktu singkat ia telah menguasai dengan baik ilmu-ilmu agama tersebut. Setelah seluruh hayatnya diabdikan untuk dunia ilmu dan kemaslahatan umat, sang Khaliq akhirnya memanggil al-Mawardi untuk selamalamanya pada usia 86 tahun yaitu pada tanggal 30 Rabiul Awal $450 \mathrm{H}$, dan dimakamkan di Bab Harb Baghdad (AlMawardi, 1994: 5).

\section{Pemikiran Al-Mawardi dalam bidang Pendidikan}

Pemikiran al-Mawardi dalam bidang pendidikan sebagian besar terkonsentrasi pada masalah etika hubungan guru dengan murid dalam proses belajar mengajar. Pemikiran ini dapat dipahami, karena dari seluruh aspek pendidikan, guru memegang peranan yang sangat penting, bahkan berada pada garda terdepan. Keberhasilan pendidikan sebagian besar bergantung kepada kualitas guru baik dari segi penguasaannya terhadap materi pelajaran yang diajarkan maupun cara menyampaikan materi pelajaran tersebut serta kepribadiannya yang baik, yaitu pribadi yang terpadu antara ucapan dan perbuatannya secara harmonis.

Al-Mawardi memandang penting seorang guru harus memiliki sikap tawadhu (rendah hati) serta menjauhi sikap ujub (besar kepala). Menurut al-Mawardi sikap tawadhu akan menimbulkan simpatik dari para peserta didiknya (Al-Mawardi, 1988: 80). Sedangkan sikap ujub akan menyebabkan guru kurang disenangi (AlMawardi, 1988: 90).

Sikap Tawadhu yang dimaksudkan al-Mawardi bukanlah sikap menghinakan diri atau merendahkan diri ketika berhadapan dengan orang lain, karena sikap ini akan menyebabkan orang lain meremehkannya. Sikap tawadhu yang dimaksud adalah sikap rendah hati dan merasa sederajat dengan orang lain dan saling menghargai. Sikap demikian akan menumbuhkan rasa persamaan, menghormati orang lain, toleransi, serta rasa senasib dan cinta keadilan (Ahmad Muhammad al-Hufi, 1968: 283).

Dengan sikap tawadhu tersebut, guru akan menghargai muridnya sebagai makhluk yang memiliki potensi, serta melibatkannya dalam kegiatan belajar 
mengajar. Prinsip ini sejalan dengan prinsip yang digunakan para pendidik di zaman modern, yaitu bahwa dalam kegiatan belajar-mengajar di masa sekarang seorang murid dan guru berada dalam kebersamaan.

Kemudian Pada perkembangan selanjutnya sikap tawadhu tersebut akan menyebabkan guru bersikap demokratis dalam menghadapi murid-muridnya. Sikap demokratis ini mengandung makna bahwa guru berusaha mengembangkan individu seoptimal mungkin. Guru tersebut menempatkan peranannya sebagai pemimpin dan pembimbing dalam proses belajar mengajar yang berlangsung dengan utuh dan luwas, dimana seluruh siswa terlibat di dalamnya.

Pelaksanaan prinsip demokratis di dalam kegiatan belajar mengajar dapat diwujudkan dalam bentuk timbal balik antara siswa dengan siswa dan antara siswa dengan guru (Rusyan A. Tabrani, 1994: 117.). Selanjutnya al-Mawardi mengatakan bahwa seorang guru selain harus bersikap tawadhu, juga harus bersikap ikhlas. Secara harfiah berarti menghindari riya, sedangkan dari segi istilah ikhlas berarti pembersihan hati dari segala dorongan yang dapat mengeruhkannya (Ali bin Muhammad al Jurjaniy, 1978: 13).

Keikhlasan ini ada kaitannya dengan motivasi seseorang. Sebagaimana kita ketahui bahwa ada guru yang mengajar karena motif ekonomi, memenuhi harapan orang tua, dorongan teman atau mengharapkan status dan penghormatan serta lainnya. Selain motif-motif tersebut seorang guru harus mencintai tugasnya. Kecintaan ini akan tumbuh dan berkembang apabila keagungan, keindahan dan kemuliaan tugas guru itu sendiri benarbenar dapat dihayati. Namun motif yang paling utama menurut al-Mawardi adalah karena panggilan jiwanya untuk berbakti kepada Allah SWT dengan tulus dan ikhlas. Lebih lanjut lagi ia mengatakan bahwa akhlak yang harus dimiliki para guru adalah menjadikan keridhoan dan pahala dari Allah SWT sebagai tujuan dalam melaksanakan tugas mengajar dan mendidik muridnya, bukan mengharapkan balasan berupa materi (Al-Mawardi, 1994: 4).

Dari Pernyataan di atas bahwa memperlihatkan dengan jelas bahwa alMawardi menghendaki agar seorang guru benar-benar ikhlas dalam melaksanakan tugasnya. Menurutnya bahwa tugas mendidik dan mengajar harus diorientasikan kepada tujuan yang luhur, yakni keridhoan Allah SWT. Sebagai konsekuensi dari orientasi semacam ini adalah pelaksanaan tugas guru dengan sebaik-baiknya serta penuh tanggung jawab.

Kemudian al-Mawardi melarang seseorang mengajar dan mendidik atas dasar motif ekonomi. Dalam pandangannya bahwa mengajar dan mendidik merupakan aktifitas keilmuan, sementara ilmu itu sendiri mempunyai nilai dan kedudukan yang tinggi, yang tidak dapat disejajarkan dengan materi. Dalam kaitan ini al-Mawardi mengatakan bahwa sesungguhnya ilmu adalah puncak segala kenikmatan dan pemuas segala keinginan. Siapa yang mempunyai niat ikhlas dalam ilmu, maka ia tidak akan mengharap mendapatkan balasan dari ilmu itu (Muntasir M. Sholeh, 1985: 141).

Itulah sebabnya dalam mendidik dan mengajar seseorang harus semata-mata mengharapkan ridha Allah. Apabila yang dituju dari tugas mengajarnya itu adalah materi, maka ia akan mengalami kegoncangan ketika ia merasa bahwa kerja yang dipikulnya tidak seimbang dengan hasil yang diterimanya. Selain itu ia sengat peka terhadap hal-hal atau persoalan yang ditemukan dalam tugasnya, misalnya soal administrasi, kenaikan pangkat, hubungan dengan kepala sekolah dan sebagainya. Tindakan dan sikapnya terhadap anak didik akan terpengaruh pula. Hal ini selanjutnya dapat merusak atau mengurangi hasil atau nilai pendidikan yang diterima anak didik (Zakiyah Derajat, 1980: 14).

Maka dengan demikian, dari uraian di atas kiranya dapat kita maknai keikhlasan seorang guru dalam mendidik adalah 
kesadaran akan pentingnya tugas, sehingga dengan kesadaran tersebut ia akan terdorong untuk mencapai hasil yang maksimal. Keikhlasan inilah akan menentukan keberhasilan tugasnya seharihari, tanpa merasakannya sebagai suatu beban, melainkan sebaliknya justru akan merasa bahagia, penuh harapan dan motivasi, karena dari tugas mengajar dan mendidiknya itu, ia kelak akan mendapatkan pahala yang setimpal dari Allah SWT.

Berdasarkan sikap ikhlas tersebut, maka seorang guru akan tampil melaksanakan tugasnya secara professional. Hal ini ditandai oleh beberapa sikap sebagai berikut: Pertama: Selalu mempersiapkan segala sesuatu yang diperlukan guna mendukung pelaksanaan proses belajar mengajar, seperti dalam penguasaan materi (bahan pelajaran), pemilihan metode, penggunaan sumber dan media pengajaran, pengelolaan kelas dan lain sebagainya. Kedua: Disiplin terhadap peraturan dan waktu, dalam keseluruhan hubungan sosial dan profesionalnya, seorang guru yang ikhlas akan bertindak tepat dalam janji dan penyelesaian tugasnya. Guru yang ikhlas akan mampu mengelola waktu bekerja dan waktu lainnya dengan perencanaan yang rasional dan disiplin yang tinggi. Ketiga: Penggunaan waktu luang akan diarahkan untuk kepentingan profesionalnya. Guru yang ikhlas, keseluruhan waktunya akan digunakan secara efisien, baik dengan tugas keguruan maupun dalam pengembangan kariernya, sehingga ia akan mencapai peningkatan. Bila sebagian waktu luang digunakan untuk hal-hal yang berada di luar tugasnya, maka guru yang ikhlas akan menggunakannya secara bijaksana dan produktif serta tidak mengganggu tugas pokoknya. Keempat: Ketekunan dan keuletan dalam bekerja. Guru yang ikhlas akan menyadari pentingnya katekunan dan keuletan bekerja dalam pencapaian keberhasilan tugasnya. Oleh karenanya ia akan selalu berusaha menghadapi kegagalan tanpa putus asa dan mengatasi segala kesulitan dengan penuh kesabaran, sehingga akhirnya program pendidikan yang telah ditetapkannya akan berjalan sebagaimana mestinya serta mencapai sasaran.

Di samping itu, keuletan dan ketekunan yang ditampilkan guru sebagai pribadi yang utuh, akan terbiasa melakukan suatu tugas atau pekerjaan yang ulet, tekun, penuh kesungguhan dan ketelitian. Kelima: Memiliki daya kreasi dan inovasi yang tinggi. Hal ini timbul dari kesadaran akan semakin banyaknya tuntutan dan tantangan pendidikan masa mendatang, sejalan dengan kemajuan imu pengetahuan dan teknologi. Guru yang ikhlas akan terus mengevaluasi dan mengadakan perbaikan proses belajar mengajar yang telah digunakannya selama ia bertugas. Lebih jauh dari itu, guru tersebut akan mempelajari kelemahan dan kelebihan dari berbagai teori dan konsep yang dapat digunakan dalam proses belajar mengajar yang diterapkan para pendahulunya, untuk selanjutnya dilakukan penyempurnaan dan pengayaan. Mengingat tugas keguruan tidak dapat dipolakan secara mekanis, eksak dan dengan resep tunggal serta tak terbatasnya variasi tindakan keguruan, maka guru dituntut untuk mampu bertindak kreatif.

Dalam kaitannya dengan keikhlasan tersebut, al-Mawardi juga berbicara tentang gaji. Dalam hubungan ini, al-Mawardi mengatakan bahwa di antara akhlak yang harus dimiliki seorang guru adalah membersihkan diri dari pekerjaan-pekerjaan syubhat dan menguras tenaga. Hendaknya ia merasa cukup atas penghasilan yang dicapai dengan mudah, dari pada penghasilan yang dicapai dengan susah payah. Guru harus meninggalkan pekerjaan yang syubhat, karena perbuatan syubhat akan berakibat dosa. Pahala lebih baik dari dosa dan kemuliaan lebih pantas dibandingkan dengan kehinaan (Al-Mawardi, 1994: 112).

Dari pernyataan al-Mawardi diatas mengisyaratkan bahwa bagian dari kegiatan mendidik adalah memberikan teladan. Oleh karena itu dalam memberikan ilmu kapada muridnya, seorang guru dituntut memiliki kejujuran dengan menerapkan apa yang diajarkan dalam kehidupan pribadinya. 
Dengan kata lain, seorang guru harus konsekuen dalam menjaga keharmonisan antara ucapan, larangan dan perintah dengan amal perbuatannya sendiri. Selain sebagai teladan, seorang guru juga harus tampil sebagai penyayang. Guru merupakan aktor kedua setelah orang tua dalam memberikan modal atau bekal dasar kepada anak-anaknya.

Oleh karenannya, guru sebagai pendidik profesional dituntut untuk berperan sebagai orang tua di sekolah. Dengan kedudukannya yang demikian, maka seorang guru harus memiliki sifat kasih sayang dan lemah lembut terhadap muridnya. Dalam hubungan ini, al-Mawardi mengatakan bahwa diantara akhlak seorang guru adalah tidak berlaku kasar kepada muridnya, tidak boleh menghina murid yang sedang berkembang, tidak boleh memandang rendah murid-muridnya. Karena semua itu akan membuat mereka lebih tertarik, terkesan, dan bersemangat (Musthofa, 142).

Selanjutnya al-Mawardi menegaskan tentang tugas dan peran guru sebagai pembimbing. Bimbingan dapat diartikan sebagai kegiatan memantau murid dalam perkembangannya dengan jalan menciptakan lingkungan dan arahan sesuai dengan tujuan pendidikan. Sedangkan dari segi bentukya bimbingan tersebut dapat berupa pemberian petunjuk, teladan, bantuan, latihan, penerangan, pengetahuan, pengertian, kecakapan dan keterampilan, nilai-nilai, norma serta sikap yang positif. Dalam kaitan ini al-Mawardi mengatakan, di antara kewajiban guru adalah memberikan nasihat atau bimbingan kepada muridnya, kasih sayang, mempermudah jalan bagi muridnya, berusaha keras menolong dan membantu muridnya. Semua itu akan menghasilkan pahala yang besar, keluhuran namanya, serta semakin bertambah dan menyebar ilmunya (Musthofa, 113).

Bentuk-bentuk bimbingan tersebut selanjutnya adalah dengan jalan membantu murid-murid untuk mengembangkan pemahaman diri sesuai dengan kecakapan, minat, pribadi, hasil belajar serta kesempatan yang ada, membantu proses sosialisasi dan sensivitas kepada kebutuhan orang lain, mengembangkan motif-motif intrinsik dalam belajar sehingga tercapai kemajuan pengajaran, memberikan dorongan dalam pengarahan diri, pemecahan masalah, pengambilan keputusan, dan keterlibatan diri dalam proses pendidikan, mengembangkan nilai dan sikap secara menyeluruh serta perasaan sesuai dengan penerimaan diri sendiri, memahami tingkah laku manusia, membantu murid-murid untuk memperoleh kepuasan pribadi dan dalam penyesuaian diri secara maksimum terhadap masyarakat serta membantu aspek fisik, mental dan social (Zuhairini, 1992: 65).

\section{Pola Interaksi Pembelajaran}

Menurut Al-Mawardi, untuk mencapai keberhasilan yang maksimal dalam proses pendidikan, harus diperhatikan Sembilan perkara yang akan berpengaruh pada proses tersebut. Adapun kesembilan perkara tersebut yaitu: Pertama, Akal yang dapat menangkap hakikat dari sesuatu. Kedua, kecerdasan yang dapat menyingkap rahasia pengetahuan. Ketiga kekuatan ingatan untuk menyimpan memori-memori pengetahuan. Keempat, semangat yang dapat memalingkan diri dari rasa malas dan bosan kelima, mencukupkan pada mempermudah materi yang tidak perlu di buat sulit. keenam, konsentari. etujuh, tidak adanya penghalang yang dapat mengacaukan. kedelapan, pendidikan dilaksanakan sepanjang hayat. kesembilan, adanya bimbingan guru dalam proses pendidikan (Al-Mawardi, 1994: 74-75).

Dengan demikian untuk memperoleh Ilmu yang baik seorang murid harus selalu berusaha ada didekat guru dan selalu hormat kepada guru walaupun simurid lebih tinggi derajadnya. Menurut Al-Mawardi Guru lebih berhak untuk dihormati karena ilmunya. Dalam proses pembelajaran, menurut Al-Mawardi seorang 
guru harus mengembangkan suasana lapang yang memungkinkan murid untuk mengapresiasikan potensinya. Selain itu seorang guru tidak boleh menjadikan pembelajaran terfokus pada dirinya (teaching center).

Guru harus bisa mengembangkan pola interaktif dalam pemberlajaran karena masing-masing siswa membawa potensi sendiri-sendiri, dan dalam pembelajaran guru tidak boleh merasa paling menguasai materi, karena dapat dimungkinkan murid mengetahui informasi lebih dalam dari guru atau justru kebenaran akan hakikat pengetahuan itu datang dari murid, sehingga guru pun dapat mengambil manfaat dari pola pembelajaran tersebut. Pola hubungan interaksi antara pendidik dan anak didik yang dikembangkan oleh Al-Mawardi ini, agaknya menyiratkan pada sebuah pemahaman bahwa

Pendidikan itu lebih ditekankan pada aspek anak didik. Guru dalam proses pendidikan ini berfungsi sebagai fasilitator dan pembimbing untuk mengarahkan murid pada pengembangan potensi yang dimilkinya. Peran guru bukan hanya sebagai trasmitor pengetahuan (knowleg) kepada anak didik tersebut.

\section{Nilai-nilai Pendidikan Islam}

Nilai telah diartikan oleh para ahli dengan banyak pengertian. Pengertian yang satu berbeda dengan pengertian yang lain karena nilai mempunyai hubungan yang sangat erat dengan pengertian-pengertian dan aktifitas manusia yang kompleks dan sulit ditentukan batasannya. Milton Rokeach dan James Bank mengemukakan bahwa nilai adalah: "Suatu tipe kepercayaan yang berada dalam ruang lingkup sistem kepercayaan dalam mana seseorang bertindak atau menghindari suatu tindak-an, atau mengenai yang pantas atau tidak pantas (M. Chabib Thoha,1996: 60).

Dari definisi di atas bahwa nilai-nilai sering digunakan secara sempit dalam kehidupan sehari-hari. Dari sini dapat diketahui bahwa istilah nilai mempunyai pegertian yang sangat sama dengan kebaikan. Dalam masalah ini yang terpenting adalah relasi antara yang baik dengan kewajiban. Misalnya, guru dalam berhubungan atau berkomunikasi dengan murid harus mempunyai tatanan nilai yang baik, sehubungan dengan tugas dan wewenang dia sebagai seorang guru. Seorang anak atau peserta didik akan memperhatikan dan menirunya.

\section{Macam-macam Nilai}

Menurut M Chabib Thoha, dalam bukunya Kapita Selekta Pendidikan Islam, bahwa untuk lebih memperjelas tentang nilai, maka nilai dapat dibedakan dari beberapa klasifikasi (M. Chabib Thoha,1996: 63). Antara lain: a. Dilihat dari segi kebutuhan hidup manusia, nilai menurut Abraham Maslow dapat dibedakan menjadi: 1) nilai Biologis, 2) nilai keamanan, 3) nilai cinta kasih, 4) nilai harga diri, 5) nilai jati diri.

b. Dilihat dari kemampuan jiwa manusia untuk menangkap dan mengembangkannya: 1) nilai yang statik, seperti kognisi, emosi, dan psikomotor, 2) nilai yang bersifat dinamis, seperti motivasi berprestasi, motivasi berafiliasi, motivasi berkuasa. c. Dilihat dari proses budaya: 1) nilai ilmu pengetahuan, 2) nilai ekonomi, 3) nilai keindahan, 4) nilai politik, 5) nilai keagamaan, 6) nilai kekeluargaan, 7) nilai kejasmanian. d. Dilihat dari pembagian nilai: 1) nilai-nilai subyektif, 2) nilai-nilai obyektif metafisik. e. Nilai berdasar dari sumbernya: 1) nilai Ilahiyah (Ubudiyah dan Mu'amalab), 2) nilai Insaniyah, nilai yang diciptakan oleh manusia atas dasar kriteria manusia itu juga. f. Dilihat dari segi ruang lingkup dan keberlakuannya: 1) nilai-nilai universal, 2) nilai-nilai lokal.

\section{Nilai Aqidah}

Aqidah adalah bentuk masdar dari kata 'aqada, ya'qidu, 'aqdan-'aqidatan yang 
berarti simpulan, ikatan, sangkutan, perjanjian dan kokoh. Sedang secara teknis, aqidah berarti iman, kepercayaan dan keyakinan. Tumbuhnya kepercayaan tentunya di dalam hati, sehingga yang dimaksud aqidah adalah kepercayaan yang menghujam atau tersimpul di dalam hati (Tadjab, Muhaimin, Abd. Mujib, 1994: 241 242). M. Hasbi Ash Shiddiqi mengatakan aqidah menurut ketentuan bahasa (bahasa arab) ialah sesuatu yang dipegang teguh dan terhunjam kuat di dalam lubuk jiwa dan tak dapat beralih darinya (Syahminan Zaini, 1983: 51)

Dari nilai akidah di atas bahwasanya menunjukan se orang guru harus memiliki akidah yang baik terhadap peserta didik serta menjaga batas batasan dalam ucapan dalam kelas, meskipun dalam penyampain materi ada kata kata yang di seleipkan agar siswa tidak bosan dengan materi yang di sampaikan, namun dari itu semua harus menjaga batasan agar peserta didik menilai kita sebagai guru mampu dengan baik menunukan akidahnya terhadap peserta didik.

\section{Fungsi Akidah}

Pertama, Menuntun dan mengemban dasar ketuhanan yang dimiliki oleh manusia sejak lahir. Manusia sejak lahir telah memiliki potensi keberagamaan (fitrah), sehingga sepanjang hidupnya manusia membutuhkan agama dalam rangka mencari keyakinan terhadap Allah SWT. Aqidah Islam berperan memenuhi kebutuhan fitrah manusia tersebut, menuntun dan mengarahkan manusia kepada keyakinan yang benar tentang Allah SWT.

Kedua, Memberikan ketenangan dan ketentraman jiwa. Agama sebagai kebutuhan fitrah manusia akan senantiasa menuntut dan mendorongnya untuk terus mencarinya. Aqidah memberikan jawaban yang pasti, sehingga kebutuhan rohaniahnya dapat terpenuhi. Misalnya, seseorang yang berkeyakinan bahwa setiap rizki dan segala ketentuannya sudah ditetapkan oleh Allah
SWT akan merasa tenang dan tidak khawatir akan rizki yang didapatnya setiap hari. Bahwa setiap orang berikhtiar untuk menjemput rizki yang telah ditetapkan merupakan sebuah kewajiban. Akan tetapi ketika telah masuk pada persolan hasil, mutlak hak priogatif Allah swt. Oleh karena itu, seseorang yang mempunyai akidah yang mantap tidak akan pernah khawatir dan hidupnya akan senantiasa berada ketenangan.

Ketiga, Memberikan pedoman hidup yang pasti. Keyakinan terhadap Allah SWT yang diberikan kepada manusia berfungsi memberikan arahan dan pedoman yang pasti, sebab aqidah menunjukan kebenaran keyakinan yang sesungguhnya. Aqidah memberikan pengetahuan berasal dari apa dan dari mana manusia diciptakan. Dengan mengetahui jawaban ini minimal akan memberikan manfaat bahwa tidak ada yang dapat manusia sombongkan, kecuali yang "Maha Sombong". Aqidah Islam sebagai keyakinan akan membentuk perilaku bahkan mempengaruhi kehidupan seorang muslim. Abu al-A'la Al-Maududi menyebutkan pengaruh aqidah tauhid sebagai berikut: a) Menjauhkan manusia dari pandangan yang sempit dan picik; b) Menanamkan kepercayaan terhadap diri sendiri dan tahu harga diri; c) Menumbuhkan sifat rendah hati dan khidmat; d) Membentuk manusia menjadi jujur dan adil; e) Menghilangkan sifat murung dan putus asa dalam menghadapi setiap persoalan dan situasi; f) Membentuk pendirian yang teguh, kesabaran, ketabahan dan optimism; g) Menanamkan sifat kesatria, semangat dan berani; tidak gentar menghadapi resiko, bahkan tidak takut kepada maut; h) Menciptakan sikap hidup damai dan ridlä; i) Membentuk manusia menjadi patuh, taat dan disiplin menjalankan peraturan ilahi (www.Lenterakita.com, diakses 21 oktober 2017).

\section{Strategi Penanaman Nilai-Nilai Pendidikan Islam pada Peserta Didik}


Secara umum, strategi merupakan garis besar untuk bertindak dalam usaha untuk mencapai sasaran yang telah ditentukan dan sebagai pola-pola umum kegiatan guru beserta pesera didik dalam mewujudkan kegiatan belajar mengajar untuk mencapai tujuan yang telah digariskan (Djamar dan Zain, 2006: 5)

Jika dikaitkan dalam dunia pendidikan, strategi diartikan sebagai perencanaan yang berisi tentang rancangan kegiatan yang didesain untuk mencapai tujuan pendidikan tertentu. Pengertian tersebut dapat disimpulkan sebagai rencana tindakan (rangkaian kegiatan) termasuk metode dan pemanfaatan sumber daya (guru maupun peserta didik) dalam penggunaan strategi sebagai upaya pencapaian tujuan pembelajaran agar tercapai dengan optimal dan baik.

\section{Keteladanan}

Keteladanan dalam bahasa arab disebut uswah, iswah, qudwah, qidwah yang berarti perilaku baik yang dapat ditiru oleh orang lain (Armai Arief, 2002: 112). Dalam membina dan mendidikan anak (peserta didik) tidak hanya dapat dilakukan dengan cara model-model pembelajaran modern, tapi juga dapat dilakukan dengan cara pemberian contoh yang teladan kepada orang lain. Penggunaan metode keteladanan ini dapat tercapai dengan maksimal jika seluruh keluarga lembaga pendidikan menerapkan atau mengaplikasikan dengan mantap. Misalnya seorang ayah yang menyuruh anaknya untuk mengerjakan ibadah sholat, sedangkan ayahnya tidak memberikan contoh dan langsung bergegas mengerjakan ibadah solat.

Dengan demikian bahwa Guru sebagai teladan yang baik bagi peserta didiknya hendaknya menjaga dengan baik perbuatan maupun ucapannya sehingga naluri anak yang suka menirukan dan mencontoh dengan sendirinya akan mengerjakan apa yang dikerjakan maupun yang sarankan oleh guru. Perbuatan yang dilihat oleh anak, secara otomotasi akan masuk kepada jiwa kepribadian si anak, kemudian timbul sikap-sikap terpuji pada perilaku anak tersebut.

\section{Landasan Nilai Pendidikan Islam}

Secara cpistemologis, pendidikan Islam diletakkan pada dasar-dasar ajaran Islam dan seluruh perangkat kebudayaannya. Dasar-dasar pembcntukan dan pengembangan pendidikan Islam yang pertama dan utama tentu saja adalah A1Qur'an dan Sunnah (Hasan Langgulun, dkk, 1980: 96-202.). Dalam pendidikan Islam, Sunnah Nabi mempunyai dua fungsi, yaitu : (1) menjelaskan sistem pendidikan Islam yang terdapat dalam Al-Qur'an yang umumnya masih bersifat global, (2) menyimpulkan metode pendidikan dari kehidupan Rasulululah bersama sahabat, perlakuannya terhadap anak-anak, dan pendidikan keimanan yang pernah dilakukannya (Abdurrahman An-Nahlawi, 1992: 47).

\section{Keimanan dan Ketaqwaan}

Aktivitas seorang Muslim di bidang apapun, menurut konsep Islam harus didedikasikan untuk meningkatkan kualitas iman dan taqwa. Sebab, itulahu ultimatepurpose manusia (QS.Al-Imran: 102). Oleh karena itu, nilai dasar pendidikan Islam adalah kcimanan dan ketaqwaan. Artinya, pendidikan Islam harus dapat menjadi wahana bagi peningkatan iman dan taqwa anak didik. Berdasarkan niIai dasar ini, proses pendidikan Islam dijalankan berdasarkan semangat ibadah kepada Allah SWT (QS.Adz-Dzariyat: 56). Ibadah dalam ajaran Islam memiriki korelasi positif bagi pemeHharaan dan peningkatan iman dan taqwa. Setiap penganut Islam diwajibkan mencari ilmu pengetahuan untuk dipahami secara mendalam yang dalam taraf selanjutnya dikembangkan dalam kerangka ibadah guna kemaslahatan ummat manusia. 
Dalam bahasa Al-Jamaly, nilai dasar ini bertujuan mengantarkan anak didik pada kcsadaran akan eksistensinya di hadapan Allah serta menyadari kcwajibankewajibannya (Muhammad Fadhil AlJamaly, 1977: 17).

Dengan demikian dalam prakteknya, nilai ini juga mesti dijadikan landasan oleh para pendidik dalam menjalankan tugasnya. Implikasi positifnya, sekalipun para guru memiki hak-hak tertentu sebagai konsekwensi langsung dari posisinya sebagai guru, pada saat yang sama harus tetap diingat bahwa tugas mengajar adalah suatu kewajiban agama yang harus tetap dilakukan dalam rangka ibadah. Di dalam konteks ini, kejujuran, tanggung jawab, sikap tawadlu' dan sebagainya merupakan prinsip-prinsip yang perlu dipegangi oleh para praktisi dalam dunia pendidikan.

\section{KESIMPULAN}

Dari urain di atas bawasanya hubungan pemikiran pendidikan $\mathrm{Al}$ Mawardi relevansinya dengan nilai-nilai pendidikan Islam antara batasan guru dengan murid di Sekolah berkaitan dengan akhlak, rendah hati, atau tawadhu, rendah hati terhadap peserta didik. Kemudian dengan paparan di ata bahwa pemikiran alMawardi dalam bidang pendidikan banyak terkonsentrasi pada masalah kepribadian seorang pendidik, kepribadian inilah yang tampaknya yang paling utama harus ditonjolkan. Sebenarnya seorang pendidik bukan hanya harus memiliki kepribadian yang baik, tetapi harus memiliki latar belakang ilmu keguruan dan penguasaan yang baik terhadap materi pelajaran yang akan diajarkan. Namun jika hal tersebut dibandingkan dengan kepribadian, tampaknya al-Mawardi lebih mengutamakan kepribadian.

Maka oleh karena itu antara nilainilai Islam dengan pemikiran al mawardi tersbut ada kesinambungan yang harus di miliki oleh se orang guru terhadap peserta didik, tentunya dalam ranah di sekolah atau lembaga pendidikan pada umumnya, kemudian se orang guru tidak hanya sebatas memberikan materi saja melainkan tugasnya sebagai pembimbing, mengarahkan serta memberikan keteladanan agar siswa bisa menggapai cita citanya. Serta memiliki ketulusan dalam mendidik.

\section{DAFTAR PUSTAKA}

Al-Ghazali. (1998). Ibya' Ulum al-Din. Cairo: Dar al-Hadis.

Al Jurjaniy, Ali bin Muhammad. (1978). Kitab al Ta'rifat. Beirut: Dar alKutub.

Al-Jamaly, Muhammad Fadhil. (1977). Nabva tarbiyat Mukminat. Al-Syirkat al Thunisiyyat U al Tauzi'.

Al-Mawardi. (1988). Adab ad-Dunya wa adDin. Cairo: Dar al-Rayan li atTurats.

(1994). al-Hawy al-Kabir. Beirut: Dar al-Kitab al-Ilmiah.

An-Nahlawi, Abdurrahman (1992). PrinsipPrinsip dan Metode Pendidikan Islam. Bandung: CV. Diponegoro.

Arief, Armai. (2002). Pengantar Ilmu dan Metodologi Pendidikan Islam. Jakarta: Ciputat Press.

Aryati, Aziza. Pemikiran Pendidikan Al Mawardi At-Ta'lim, Vol. 15, No. 1, Januari 2016.

As-Saqo, Musthofa. (1995). Adab al-Dunya wa al-Din. Beirut: Dar al Fikr.

Chabib, Thoha M. (1996). Kapita Selekta Pendidikan Islam. Yogyakarta: Pustaka Pelajar.

Darajat, Zakiyah. (1980). Kepribadian Guru. Jakarta: Bulan Bintang.

Katsir, Ibnu. (1998). al-Bidayah Wa anNihayah. Cairo: Dar Al-Hadis.

Langgulun, Hasan (1980). Beberapa Pemikiran tentang Pendidikan Istam. Bandung: Al-Ma'anf.

Mircea Eliade, Charles J. Adams, The Encyclopedia Of Religion vol. 9.

Muhaimin, Abdul Mujib. (1993). Pemikiran Pendidikan Islam; Kajian Filosofis dan 
Kerangka Dasar Operasionalisasinya. Bandung: Trigenda Karya.

Sholeh, Muntasir M. (1985). Mencari Evidensi Islam. Jakarta: Rajawali.

Sulaiman, Fathiyah Hasan. (1986). Konsep Pendidikan al-Ghazali. Jakarta: P3M.
Tabrani, Rusyan A. Kemampuan Guru dalam Proses Mengajar. Bandung: Remaja

Zain, Djamar. (2006). Strategi Belajar Mengajar. Jakarta: PT. Rieneka Cipta. Zuhairini. (1992). Sejarah Pendidikan Islam. Jakarta: Bumi Aksara. 